Article

\title{
Disrupting Risk Governance? A Post-Disaster Politics of Inclusion in the Urban Margins
}

\author{
Ricardo Fuentealba * and Hebe Verrest \\ Department of Human Geography, Planning and International Development, Amsterdam Institute for Social Science \\ Research, University of Amsterdam, 1018 WV Amsterdam, The Netherlands; E-Mails: r.fuentealba@uva.nl (R.F.), \\ h.j.I.m.verrest@uva.nl (H.V.) \\ * Corresponding author
}

Submitted: 30 April 2020 | Accepted: 14 July 2020 | Published: 31 August 2020

\begin{abstract}
Facing climate emergency and disaster risks, cities are developing governing arrangements towards sustainability and resilience. Research is showing the ambivalent results of these arrangements in terms of inclusion and (in)justice, as well as their outcomes in emptying the 'properly political' through depoliticised governing techniques. Acknowledging this post-political thesis, however, critical analyses must also engage with re-politicization and focus on disruptive and transformative governance efforts. This article addresses the dual dynamics of de-and re-politicisation, focusing on the interplay of different modes of governing urban risk. We follow the political philosophy of Jacques Rancière and related interpretations in critical urban studies to recover the politics of the city. We focus on a post-disaster area in the foothills of Santiago, Chile. After a 1993 disaster, the State constituted a mode of governing risks based on physicalist interventions that discouraged local conflicts. This techno-managerial policing order made risks invisible while favouring real estate development. However, we show how local initiatives emerge in the interstices of formal and informal arrangements that contest this course. This emerging mode of governing risk, we argue, has the potential to recover incrementally urban politics and disrupt the dominant one through an egalitarian principle on the margins. Our contribution shows that, although these modes of governance coexist and are still evolving, advancing more just and inclusive cities require moving beyond consensus-based governance and focusing on the role of dissent and disruptive politics.
\end{abstract}

\section{Keywords}

inclusive cities; Jacques Rancière; post-disaster; risk management; urban governance; urban politics

\section{Issue}

This article is part of the issue "Cities of Inclusion - Spaces of Justice" edited by Anja Nygren (University of Helsinki, Finland) and Florencia Quesada (University of Helsinki, Finland).

(C) 2020 by the authors; licensee Cogitatio (Lisbon, Portugal). This article is licensed under a Creative Commons Attribution 4.0 International License (CC BY).

\section{Introduction}

Cities face multiple challenges related to the climate emergency and disaster risks. Accordingly, a set of novel policies, institutions, and governance arrangements have emerged to create sustainable and resilient cities (UNDRR, 2017; UNISDR, 2015). Much research has reflected on the inclusiveness of these initiatives, especially in relation to low-income and vulnerable groups in urban settings (Chu, Anguelovski, \& Carmin, 2016; Gupta, Pfeffer, Ros-Tonen, \& Verrest, 2015; Mitlin \&
Satterthwaite, 2016; Vale, 2014). Others have expanded on their inherent politics and justice concerns (Fainstein, 2015; Kaika, 2017; Meerow \& Newell, 2016). Such reflections should be seen in the light of growing evidence that these policies, for example towards resilience, may produce exclusionary outcomes (Alvarez \& Cardenas, 2019; Weinstein, Rumbach, \& Sinha, 2019). Furthermore, questions have arisen on the democratic politics driving the coordination and reproduction of cities. These follow David Harvey's (1989) description of an urban governance shift from a managerial logic into 
an entrepreneurial one, where competition and marketbased development become primary forces. Lately, critical researchers have deemed consensus-based governance processes as non-democratic and post-political (Dikeç, 2005; Dikeç \& Swyngedouw, 2017; Swyngedouw, $2007,2010)$. Since the usage of techno-managerial logics evacuates and even forecloses the 'properly political' (Swyngedouw, 2009), it is important to consider the depoliticised contexts where these urban initiatives might emerge. This requires reflecting on the dynamics of deand re-politicising urban governance on the ground.

Post-disaster contexts are interesting for examining such dynamics, given the widespread inequality of urban risks and the contentious character of disasters (Hewitt, 1983; Oliver-Smith, Alcántara-Ayala, Burton, \& Lavell, 2017). While considering emergent exclusions from relief and recovery, post-disaster risk governance also sets forth long term interventions with ambivalent outcomes in terms of inclusion (Gotham, 2016; Gotham \& Greenberg, 2014; Ingram, Franco, del Rio, \& Khazai, 2006). Moreover, reducing the political to technomanagerial modes of governance is "particularly relevant in environmental practices" (Swyngedouw, 2009, p. 605). In line with this assertion, urban planners and policymakers regularly prefer 'physicalist' interventions to manage risks (Hewitt, 1983), constructing more visible initiatives and showing powerful stakeholders how governance actors respond to risks (Pelling, 2003). However, managing risks is far from a technical issue, as "the choice, design standards and delivery of engineering projects are embedded in the politics and power relations of the city" (Pelling, 2011, pp. 383-84). In this regard, reducing risk management efforts into a technical issue is an important strategy for their depoliticization (Ferguson, 1994; Li, 2007). Risk management is thus intimately connected to historical vulnerabilities and associated spatial (in)justices that influence their effectiveness and inclusiveness (Huang, 2018; Nygren, 2018).

In this article, we examine the dynamics of urban politics in relation to risk management practices in a post-disaster context. This requires focusing on the politics of risks, which has been addressed by a number of contributors (Fraser, 2016, 2017; Nygren, 2016, 2018; Rebotier, 2012; Zeiderman, 2012, 2013). For example, Fraser (2016) analyses urban risks and adaptation in informal settings in Colombia, reflecting on the importance of non-expert and local knowledge to risk responses. From a Foucauldian approach based on biopolitics and governmentality, Zeiderman (2012) addresses risk as a subject of technology, and as such, in need of continuous work to make it a realm of governmental intervention (e.g., through a set of practices, meanings, and techniques). This work is critical as neoliberal urban development renders post-disaster communities to be responsible to manage their vulnerabilities (Nygren, 2016). While these debates show the tensions in risk governance regimes, a less explored dimension is how different modes of risk management interact, contest, and poten- tially enhance a politics of inclusion. Cities are profoundly political in terms of enablers or restrictors of equality (Davidson, 2016). For that, we acknowledge the debate on post-political cities but focus on the potential to recover urban politics through disruptive processes in the name of equality (Davidson \& Iveson, 2015; Dikeç, 2017). Such urban politics dynamics exist in how governance structures depoliticise social movements (Uitermark \& Nicholls, 2014), and can co-exist with different outcomes: as described by Choplin (2016), slum clearance programs and subaltern politics of resistance have, respectively, depoliticization and re-politicisation effects.

Following a similar line of thought, we aim to analyse the interrelation of different modes of risk management and their potential results. We develop an approach inspired by the French philosopher Jacques Rancière and unpack an analytical lens into these modes using his ideas of 'policing' and efforts to recover an egalitarian politics. Rancière can contribute to delineate inclusive cities following a radical notion of equality that can potentially disrupt its governing order and recover the political character of cities. This has relevance for understanding spatial practices as well as discursive dimensions of the politics of inclusion, as this frame questions critically who counts as a legitimate actor of intervention and whose risks are addressed. To show this empirically, we focus on an area in the foothills of the Andes in Santiago, Chile, affected by a disaster in 1993. The question guiding the article is: Under what conditions does the interplay of different modes of governing risks advance more inclusive cities, and what is the role of politics in that process?

Up next, we expand further our framework based on Jacques Rancière. Then we describe the research design, followed by the results and a discussion section. The final section presents the conclusions.

\section{A Rancièrean Politics of Inclusion for Urban Disaster Governance}

Among critics of current political conditions of capitalism (e.g., Mouffe, 2005), Jacques Rancière has become a key figure in critical theory today (Keucheyan, 2013). His philosophy stems from a political ontology intending to reflect on the 'properly political,' and has influenced academic fields including critical strands of geography and urban studies (Davidson \& Iveson, 2015; Dikeç, 2005; Dikeç \& Swyngedouw, 2017; Swyngedouw, 2009, 2011; Velicu \& Kaika, 2017). In our discussion, his approach is relevant because governance analyses require a strong and critical theoretical base to "identify and foster possibilities for a renewed urban politics" (Davidson \& Iveson, 2015 , p. 544). His philosophy begins with an extreme position about equality. For Rancière, equality is not a goal, but an ontological presupposition, it is an egalitarian principle (Rancière, 1991). From this starting point, two central concepts for understanding governance critically are the police and politics. 
For Rancière, there is always a governing process he names the 'police,' corresponding to an imposed order through which society organises its functioning. The police are always in tension with the egalitarian principle and are thus by definition unequal. Supposedly based on consensus, the police define and allocates certain "ways of doing, ways of being, and ways of saying and sees that those bodies are assigned by name to a particular place and task" (Rancière, 1999, p. 29). Although the police and the act of policing do not coincide with the State apparatus, it is the law through which certain shares are distributed. Echoing aesthetics, Rancière calls this "the partition of the sensible" (le partage du sensible; Rancière, 2010, p. 36). The police orders what is visible and the sayable: It defines why "a particular activity is visible and another is not, that this speech is understood as discourse and another as noise" (Rancière, 1999, p. 29). Viewed like this, the police can be applied to urban governance, in the sense of a set of regulatory arrangements coordinating and reproducing cities, providing a way to analyse the processual mode in which urban power is exercised (Davidson, 2017; Davidson \& Iveson, 2015). This includes bureaucracies, practices, instruments, and discourses passing as technical interventions that mask their ideological character, along with how they delineate a certain sensibility.

While the police arrange groups in particular places within society, the essence of politics is to disturb this order. 'Properly political' events, characterised as disruptive and aiming towards dissensus (Rancière, 2010), are rare and infrequent: Politics only emerges when "the part of those who have no part" interrupt the natural order of domination in the name of equality (Rancière, 1999, p. 30). "Politics, before all else, is an intervention in the visible and the sayable" (Rancière, 2010, p. 37), making it the counterpoint of the police. Making noticeable that which was previously invisible is central here, as political activity "makes visible what had no business being seen...it makes understood as discourse what was once only heard as noise" (Rancière, 1999, p. 30). The clash between the police and a part mobilised by an egalitarian principle requires a spatial counterpart. Rancière's position is that political communities disrupting the police always do so through "intervals of subjectification," which are constructed "between identities, between spaces and places" (Rancière, 1999, p. 137). In that sense, these 'in-between spaces' are multiple. Although politics is exceptional, it can emerge everywhere: As there is no 'no police,' that is, no place lacking a logic distributing the sensible, politics can emerge anywhere. Civil rights movements provide examples of this formation of subjectivities: The defiance of Rosa Parks to change her bus seat in 1955 or the counter sit-in staged by four black students in 1964 at a 'whites-only' space, are instances where equality is presupposed and thus properly political (May, 2008; Rancière, 2006). Critical geographers have expanded this to renovate spatial politics. For Swyngedouw, 'egalitarian spaces' refer to a "socio- spatial configuration through performative practices of dissensual spatialization" (Swyngedouw, 2011, p. 375). Davidson and Iveson (2015) use Rancière to explore the city as a space through which politics is staged, and relatedly, a community of emancipation. The latter connotation has been used for discussing resilience as resistance (Boano, 2017), enhancing a more active role of communities in adaptation towards dissent, and ultimately transcending top-down adaptation programmes by verifying their perpetual equality.

How does Rancière's philosophy help to understand the interplay of different modes of risk governance and their politics of inclusion? Three ideas guide our analysis. First, disaster risk management structures, especially those following techno-managerial and physicalist forms, delineate the visible and sayable for dealing risks. Understood as a 'police governing' order, we unpack the historical constitution and socio-spatial effects of a dominant mode of governing risks. Second, to identify initiatives that potentially disrupt this order, we explore the origins, practices, and discourses of alternative risk management efforts, accounting for the demand for inclusion and potential for disrupting the police. Following Boano (2017), we recognise risk-related claims demanding equality through practices of resistance. And third, to recognise the potential political character of these initiatives, we analyse their interaction with the police, in relation to how the latter creates the conditions for their emergence. As argued by Dikeç (2005, p. 181), "if politics puts the police ordering of space to an egalitarian test, then politics is possible not despite the police, but because of it." To enhance the urban features of the political, we explore beyond formal and informal distinctions to see how risk initiatives emerge in their interstices, developing practices and discourses of risk management with justice connotations (Huang, 2018; Koster \& Nuijten, 2016; Soja, 2010).

\section{Research Design}

We conducted empirical research in the district or comuna of La Florida, in the south-east of Santiago, Chile, along the Andes. In the article, we refer to this area as the 'foothills,' as it is how local inhabitants know it (Biskupovic, 2015). We address it as 'marginal' for its socio-economic conditions and its location, as shown in Figure 1. Throughout the 20th century, this area had a rural and low-density character and its land was used mainly for agriculture and recreation. An important urbanisation process took place during the 1960s and 1970s when families migrating from other parts of Chile settled here through squatting land and/or using State housing policies. Around 1982 this area had roughly a population of 5,500 people living in six distinguishable neighbourhoods (Ampliación La Higuera, La Higuera, Fernando Dominguez, EI Progreso, El Esfuerzo, and Las Perdices). Around $10-20 \%$ of the population then was highly exposed to floods and landslides (Muñoz, 


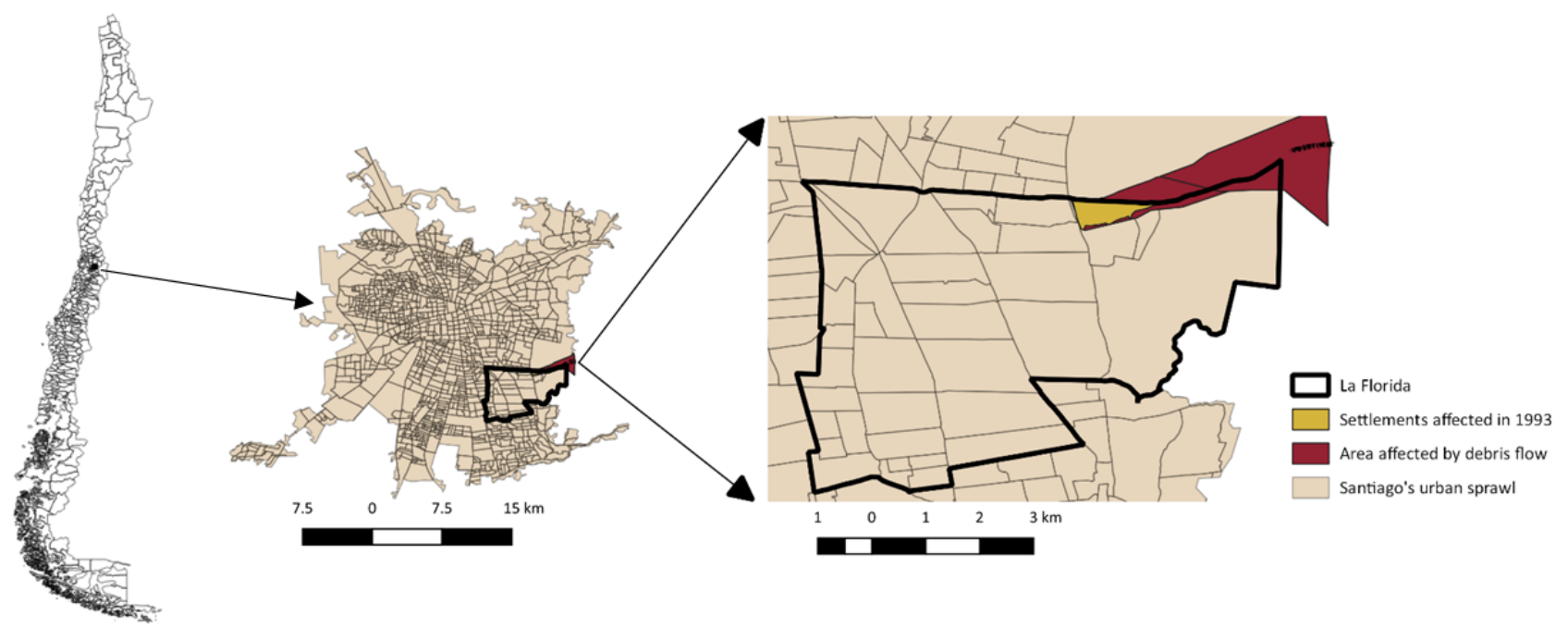

Figure 1. Research area in south-east Santiago. Source: Authors based on IDE.cl.

1990). During the 1980s they experienced a number of floods (1982, 1986, and 1987), but the main disaster to which we refer occurred on the 3 of May 1993. Then, strong rains with high temperatures produced a debris flow or 'alluvium' in the Macul Ravine, killing 23 people, destroyed two neighbourhoods (Fernando Dominguez and El Progreso) and damaging other three, and roughly 3,800 people lost their households (ONEMI, 1995). As we show below, this disaster marked the course of all risk management initiatives in the foothills.

Our research design followed qualitative and spatial methods. During the six-months of fieldwork, we conducted 48 in-depth interviews with disaster risk governance actors and residents of the foothills. Our informants were diverse in relation to their socio-economic background, as well as their historical attachment to the area. We interviewed long-term inhabitants of the foothills who experienced the 1993 disaster, new residents that have arrived in the last decade, and informants from different governmental scales working on risk and emergency management. While we refer below to the inhabitants of the foothills as a community, this does not mean this is a homogeneous group as some internal differences and tensions exist, especially between new and old residents. Our research developed a historical perspective to analyse the genealogy of the current disaster risk governance practices. For that, we incorporated life story questions in the interviews and reconstruct the informants' experiences and trajectories with risks in the foothills. We also collected and analysed secondary archival documentation related to urban policy and planning processes, newspapers, and previous research, to expand this historical approach.

During fieldwork, we visited a number of relevant places, such as the neighbourhoods affected by the 1993 disaster, the new settlement for relocated victims (the Santa Teresa village), some risk management infrastructure, and the new real estate development projects. We conducted participant observation in community meet- ings related to risk management. Access to these initiatives was granted through a long-term neighbour of this area, who introduced us to a new organisation we expand on in the following sections: the Brigada de Emergencias Alto Florida (BEAF, Alto Florida Emergency Brigade). From then, following a snow-balling principle, we met many members of the BEAF that participated as key informants. We also accompanied the work of the BEAF in different activities throughout the foothills. Finally, we used spatial analysis to provide further details on the research area, following the official repository of geographical data (at IDE.cl), complementing it with our own field experience.

\section{Results}

We structure the results in two sub-sections: first, analysing the mode of governing risks that emerged in the aftermath of the 1993 disaster as a police order; and second, analysing the BEAF as a community-based initiative that might transform the dominant mode.

\subsection{Constituting the Police: The Emergence of a Techno-Managerial Risk Governance}

The current mode of risk management in the foothills is marked by three instances: a post-disaster socioenvironmental conflict, the implementation of a land use policy, and the construction of mitigation infrastructure. We expand on the three here, arguing that have produced a techno-managerial governing order similar to the police.

After the 1993 debris flow, the regional government of Santiago adopted a new metropolitan plan: the 1994 PRMS (Plan Regulador Metropolitano de Santiago). This had two important planning consequences in the foothills: It defined risk-related land use norms that restricted development and extended Santiago's limit to the east by redefining this land as urban. From be- 
ing sparsely urbanised and given the absence of a local master plan in this area, the extension of the city's limit entailed the potential of developing the foothills with high population densities. To contest this, a socioenvironmental movement for protecting the foothills emerged against the potential real estate development. The movement was led by upper-middle-income residents of different neighbourhoods (Biskupovic \& Stamm, 2016) and was supported by local and national politicians. They demanded a land regulation to secure the area's historical low density, avoiding deforestation and erosion related to land use changes. They staged many protests throughout Santiago to make visible the potential risks associated with a private-led urban growth in the foothills. In their words, they aimed to enhance "urban planning as if the people truly mattered" (Figure 2, left) and "to inhabit the foothills with respect and conscience" (Figure 2, right).

The contrasting views between local communities and real estate companies for developing the area reached national attention. Around 1996-1997, thanks to this visibility, a municipal regulatory instrument was approved to maintain the low densities of the foothills (Res. 81, Plan Seccional Seccional Oriente, which modified the Master Land Use Plan of La Florida). However, real estate companies used their resources and the National institutional framework in their favour. Then, representatives of these companies sue the municipal government in the Chilean Supreme Court and ultimately won, rendering that regulatory instrument invalid (Rojas, 1996). With this, they were able to develop their projects, which from the perspective of the local communities, represented an ending of the foothills as a rural haven (Biskupovic, 2015). Despite some raising concerns about the sustainability of the area and likely exposure to natural hazards, the mobilisation ended abruptly and the conflict discouraged. Whereas some people maintained a critical position against the course of the area, the collective participation diminished, which is consistent with wider post-dictatorial trends in civil society and State re- lations that demobilised and rendered policymaking a technical issue (Delamaza, 2015).

Real estate companies defended their project by either neglecting the risks associated with debris flow or by referring to the State initiatives. Asked about how to avoid the formation of new alluvium, the president of the Macalto Investment company said that "the Ministry of Public Works has made a huge investment in the Macul Ravine for building terraces that stop the advancement of rocks and other materials dragged by alluviums" (P.C., 1996). From the perspective of a mobilised local inhabitant, "on paper, the [real estate companies] will be asked to [follow] many regulations but nobody will enforce them." Ultimately, four years after the 1993 debris flow, the foothills started to shift from a rural landscape towards a densified urban area comprised of highincome real estate gated communities. This entailed a very high pace of growth as shown in Figure 3, and from the population of 5,500 in the 1980s, it reached roughly 25,000 in 2017 (INE, 2017; Muñoz, 1990). The established multi-level institutions for urban planning constituted a potentially unsustainable course for the area.

Alongside this transformation, planning instruments and risk management generated two initiatives. On the one hand, the 1994 PRMS also regulated spaces exposed to risks through land-use restrictions. Therein, three risk-related norms exist: due to the Macul ravine, to flood risks, and landslide risks. Based on the impacts of the 1993 debris flow and the potential overflow of the ravines, this land use defined buffer zones where urban development was excluded or restricted to specific functions, such as recreative infrastructure or public parks (in green in Figure 3). In practice, on top of the absent participation of communities in redefining these spaces, there are uneven results between public-and private-owned areas: Whereas some private spaces developed into green parks or mitigation infrastructure along with real estate development, public institutions lacked funding to establish such green spaces. While this land use plan has allowed urban development to grow more organically
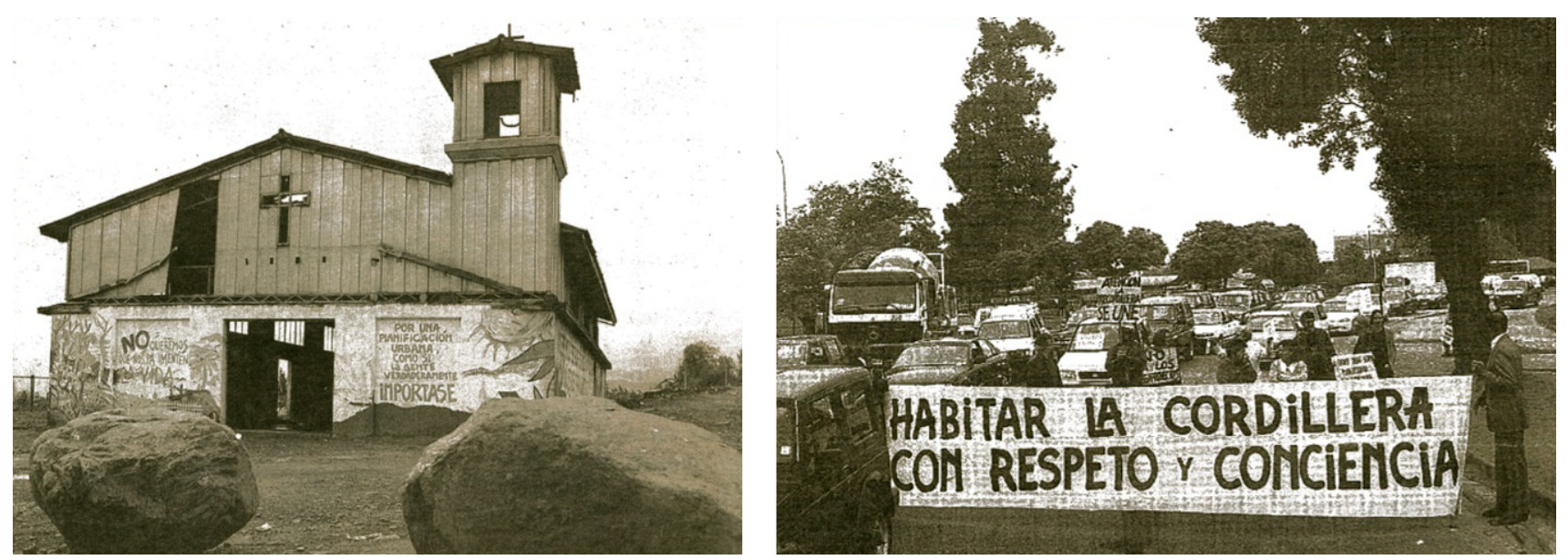

Figure 2. From left to right: The Santa Teresa Chapel (C. Gutiérrez, 1997) and a protest during the post-disaster conflict in the foothills (P. Gutiérrez, 1997). 


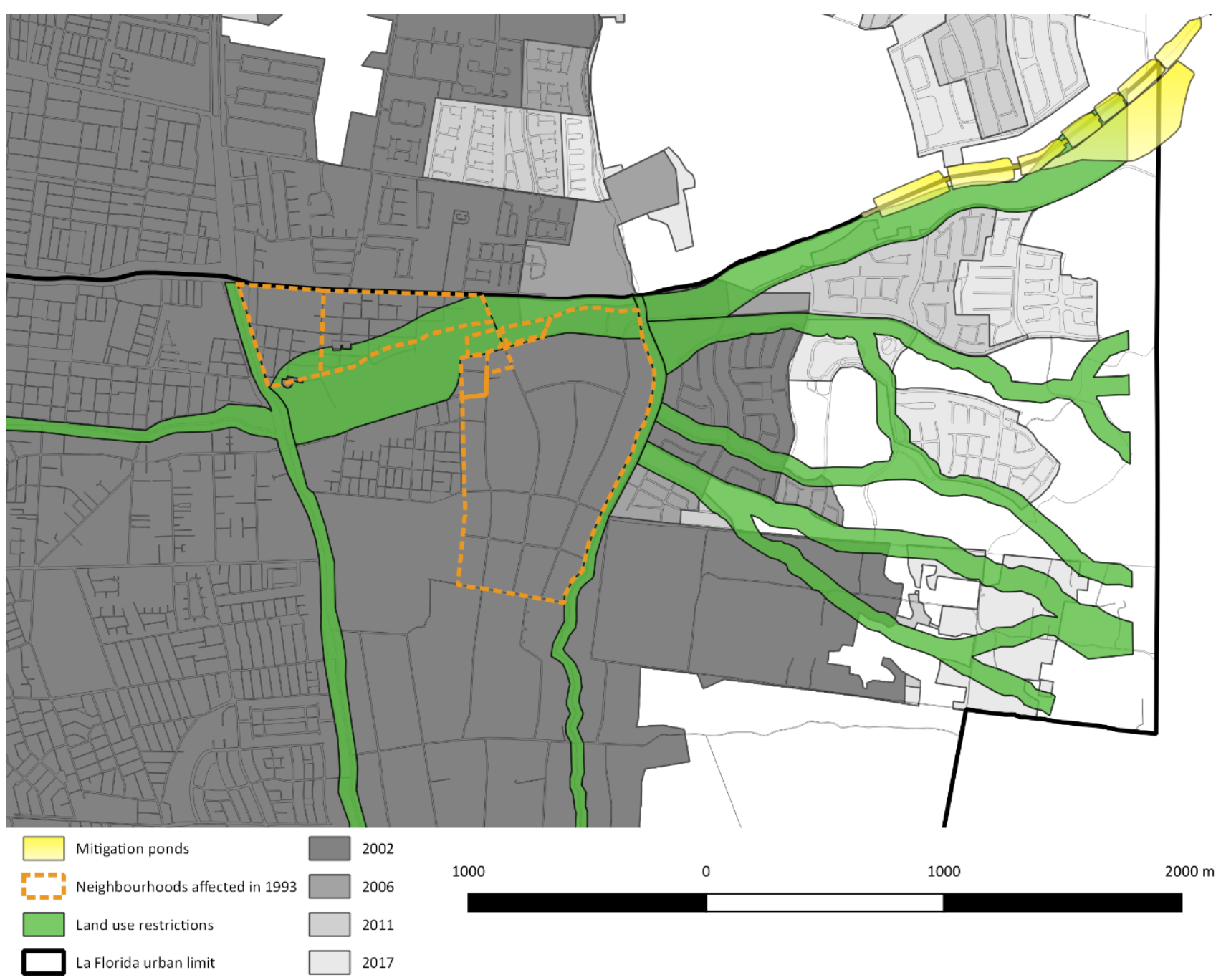

Figure 3. Development and risk management in Santiago's Foothills (1993-2017). Source: Authors based on IDE.cl.

and protected parts of the foothills, it is smaller than recommended given the high economic pressure of developing this area (Sepúlveda, Rebolledo, \& Vargas, 2006), and furthermore, it has produced further marginalisation and exclusionary effects (Fuentealba, Verrest, \& Gupta, in press).

On the other hand, the State developed a risk management initiative through the Ministry of Public Works, in the form of a hydraulic engineering project to implement in different stages (Ingenieros, 1994). It is a set of public infrastructure works, whose main component consist of seven mitigation ponds (or 'terraces,' as the real estate representative mentioned) of 1,4 kilometres long and with an average width of 50 metres for decanting the material that would be dragged by another similar event (in yellow in Figure 3 ). The ponds require permanent cleaning maintenance and an annual monitoring program (MOP, 2006), and its public investment reaches roughly 2.5 USD Million up to 2009. Experts conclude that debris flow risks from the Macul ravine are reduced with this structural intervention, as it has worked "in minor events related to intense rainfall," although is "yet to be tested in future major debris flow events" (Sepúlveda et al., 2006, p. 94). Nonetheless, this infrastructure has produced a general sense of unmanaging risks, as it is the kind of engineering works that might protect from disasters while generating a "false sense of safety" (Cutter et al., 2012, p. 293). Given the occurrence of the 1993 disaster, risk management has centred on the Macul ravine, putting other ravines in a secondary place, particularly the Santa Sofia de Lo Cañas, which 'activated' in 2005, flooding some low- and highincome areas alike. The foothills, according to scientific and risk assessments, remains at high risk to natural hazards (Ferrando, Sarricolea, \& Pliscoff, 2014; Garrido \& Sepúlveda, 2012; Sepúlveda et al., 2006; SEREMI-MINVU \& INDUAMERICANA, 2014).

The outcome of this mode of managing risks is that disaster risks are invisible, which inhabitants perceive as particularly critical given the trajectory that favoured real estate development. This trend, following our urban geographical approach inspired by Rancière, constitutes a 'policing' governing order. Risk governance delineates which discourses and spatial initiatives are deemed le- 
gitimate. This regime defined real estate companies and the State as the sole actors managing risks, discouraging efforts to contest it. Regardless of the reactiveness of Chilean disaster risk governance (Camus, Arenas, \& Lagos, 2016; Sandoval \& Voss, 2016), the outcome of the 1990s socio-environmental conflict contributed to setting the stage for entrepreneurial urban governance. The balance between environmental sustainability and private-led development leaned to the latter. Thus, as private companies disregard the presence of hazards or used strategically public infrastructure in their favour, risk management was rendered technical. This policing mode defined community mobilisations as 'noise,' external to the legitimate work of the State and private actors. While opting to develop physicalist interventions assumes consensus-based governance, in practice communities are not involved in that. This governing order distributed the sensible, delineating an uneven regime of who manage risks and vulnerabilities. As any police order nonetheless, it can be potentially transformed, so now we turn to this.

\subsection{A Demand for Inclusion in the In-Between Spaces of Vulnerability}

Practices of collective contestation against the risk management order, despite some flooding occurrences (such as in 2005), remained infrequent. Some inhabitants criticised the development trend, but a silence about disaster risks prevailed for years. One crucial exception is the work of the Network for the Protection of the Foothills (the Network, hereafter), which emerged in 2006 and consisted of community leaders and citizens organised to defend this area against real estate development. Some of the members of the Network participated in the 1990s mobilisations, and along with a younger generation of activists, raised a voice towards conservation in this area, particularly around the El Panul forest (Biskupovic, 2015). The impacts of this network are important and have worked on the background to mobilise people to preserve their environment. Alongside this effort, a new initiative emerged that is explicitly concerned about risk management. That is why in this subsection we expand more on the recent and practical experience with risks of the BEAF. As we show below, there are particularities of this initiative that might disrupt the police and thus recover a politics of inclusion in the foothills.

The BEAF started in 2013, based on a double concern from local inhabitants about prevalent risk management. First, given the marginal position of the foothills within the comuna, its neighbourhoods are very distant to main emergency services, which is critical for landslides and floods, as well as other hazards excluded in local planning such as wildfires and seismic risks. And second, given the increased hazards brought by real estate development and increased awareness of possible disasters, they realised that risk-prevention measures in the area were insufficient: physical interventions such as the ponds are important but not enough. From this, some inhabitants founded the brigade as a way to understand the hazards and develop emergency preparedness measures and enhance awareness. Given the presence of forests in the foothills (e.g., Panul), the BEAF focused initially on wildfires but has expanded to other hazards.

The BEAF has a peculiar institutional basis. It is a local emergency organisation, but one that emerged at the crossroad of other institutions, such as the firemen or the National Forestry Corporation (CONAF). As the captain of the BEAF defines it:

We are not firemen, we are not CONAF, we are not the police, we are not civil defence, we are not Red Cross. In a way, we opened a door that never existed....We are creating a new institution in Chile.

The BEAF lacks permanent resources and functions primarily with voluntaries, the majority being local residents. Being voluntary entails that its members come from different backgrounds and expertise. They participate in official training programmes from CONAF or the Red Cross, in topics such as first aid, or forestry and emergency management. Although lacking resources, the BEAF has acquired better equipment and improved its infrastructure. Figure 4 describes the space in which they intervene in La Florida, which is over 15 square kilometres. We also show the BEAF's headquarter, located in a community centre; and the Panul forest location. As the captain of the BEAF says: "It is an enormous area, with an important hazard risks associated," which requires an important preventive work. Thus, their strategy was approaching local neighbourhood associations, to make them conscious of their environment.

They have developed ties with myriad institutions and organisations. This includes State actors, although the captain remembers that initially they "closed many doors to the brigade because there was a strong opposition, particularly from the firemen companies, who saw us as a competition." On the contrary, a strong positive relationship exists with the local community. As a former president of a neighbourhood association remembers, "when [the BEAF] was forming...but did not have a place to function, I gave them permission" for settling in the neighbourhood association's centre. Depending on donations, the BEAF regularly organises funding campaigns with the community to collect resources. They have constructed a horizontal and inclusive local network, developing educational initiatives and prevention campaigns throughout the foothills. For example, in the midst of poorly organised formal networks with the State, a resident of the Santa Teresa Village states that:

The BEAF works with all the hazards, so they can teach us about all the risks, an alluvium, a flooding....We attended the inauguration of the new watchtower of the BEAF and it is wonderful, an amazing idea, and managed by our own neighbours. 


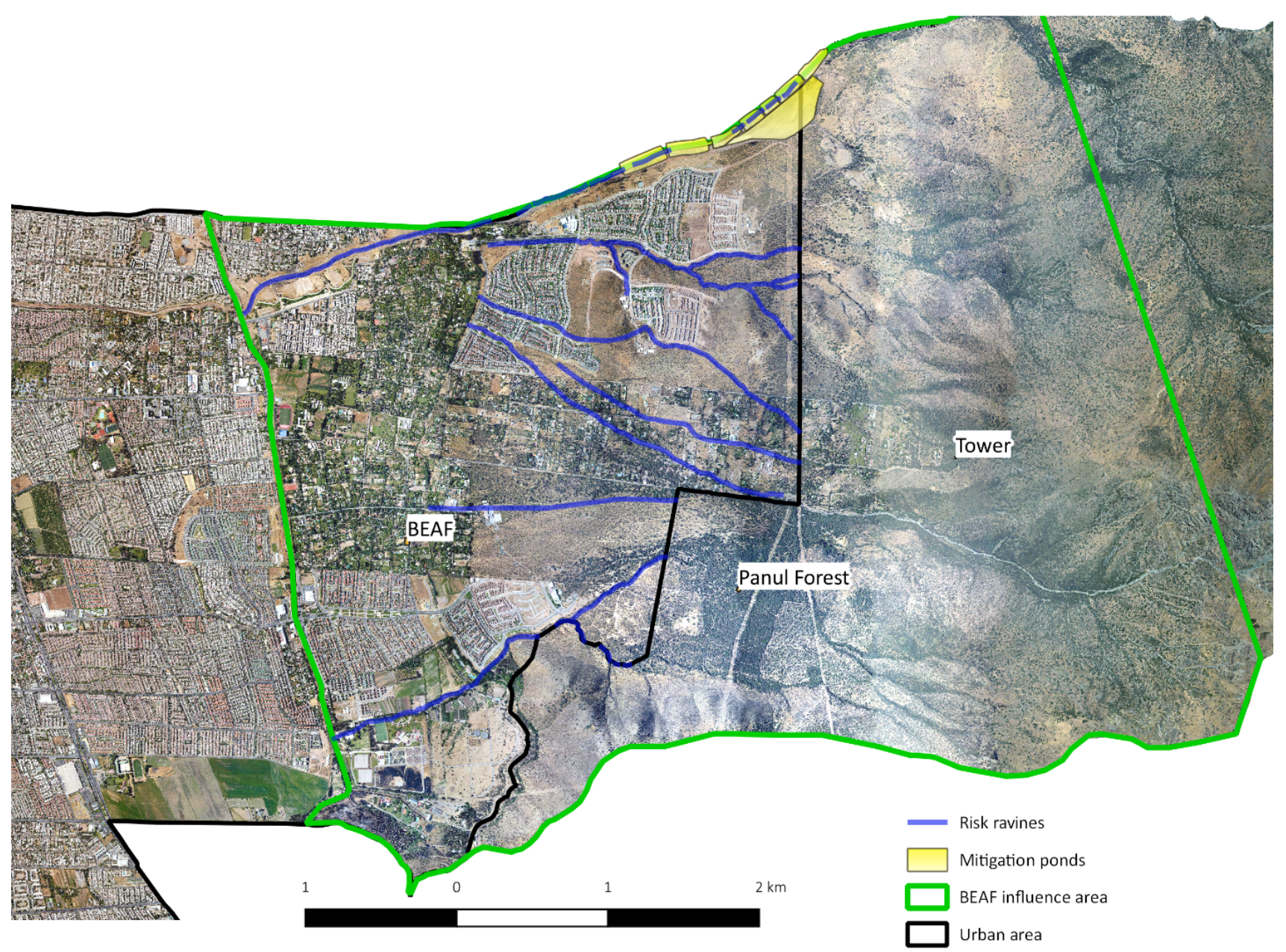

Figure 4. Map with BEAF-related places in the foothills of La Florida. Source: Authors based on interviews and IDE.cl.

There, she refers to a new project that emerged from the BEAF, as given the lack of risk-awareness initiatives in the foothills, they designed and constructed a watchtower in a higher zone of The Andes (Figure 5). Funded mainly through local donations and implemented together with CONAF who provided the lookout workers, the watchtower is five-metres high and has a visibility of over 40 kilometres and aims to help with early hazard warning.

In line with risk assessments, the BEAF voluntaries recognise the long-term vulnerabilities of the foothills. This concentrates especially in the settlements closer to the Macul Ravine (many of which had already suffered in 1993) and those in the urban-forestry interface of higher areas, urbanised by real estate companies over the last two decades. They know that one of the main problems with this private-led development is the complexity of evacuating thousands of people: As the captain warns, "in the event of an emergency, more people will die evacuating than from the catastrophe." Awaiting such a natural hazard event, the BEAF has successfully worked as a first-responder in many emergencies. In these, the close link with local communities is critical. For example, as neighbours called the BEAF directly in the case of wildfires in El Panul, they managed to arrive within four min- utes, so while affected areas used to be many hectares in size, the captain reports that "now they are less than half a hectare because of our quick first intervention." Emerging from the community and working directly with them has allowed a very close engagement with the diverse inhabitants of the foothills. A critical characteristic of this success is their being a local initiative and exposed to the same risks as the population they serve. As a BEAF volunteer puts it: "With our work in emergencies you get closer to people, you know them in different circumstances....It has helped with social integration, to recover community life, to live closer, not in isolation."

Since its inception, the BEAF is becoming an integral part of risk management in the foothills. In itself, the $B E A F$ is not an initiative intending to advance an alternative or counterhegemonic societal change. Arising from an institutional vacuum left from the prevalent mode of risk management, it maintains a close relationship with the police by interacting with formal institutions. Despite this, through the BEAF's working with neighbourhood associations and other community-based organisations such as 'the Network,' an alternative mode of risk management is emerging. Three features of the BEAF are critical for this: its egalitarian logic, its emergence 'at the margins,' and its formation of subjectivities. These three, 

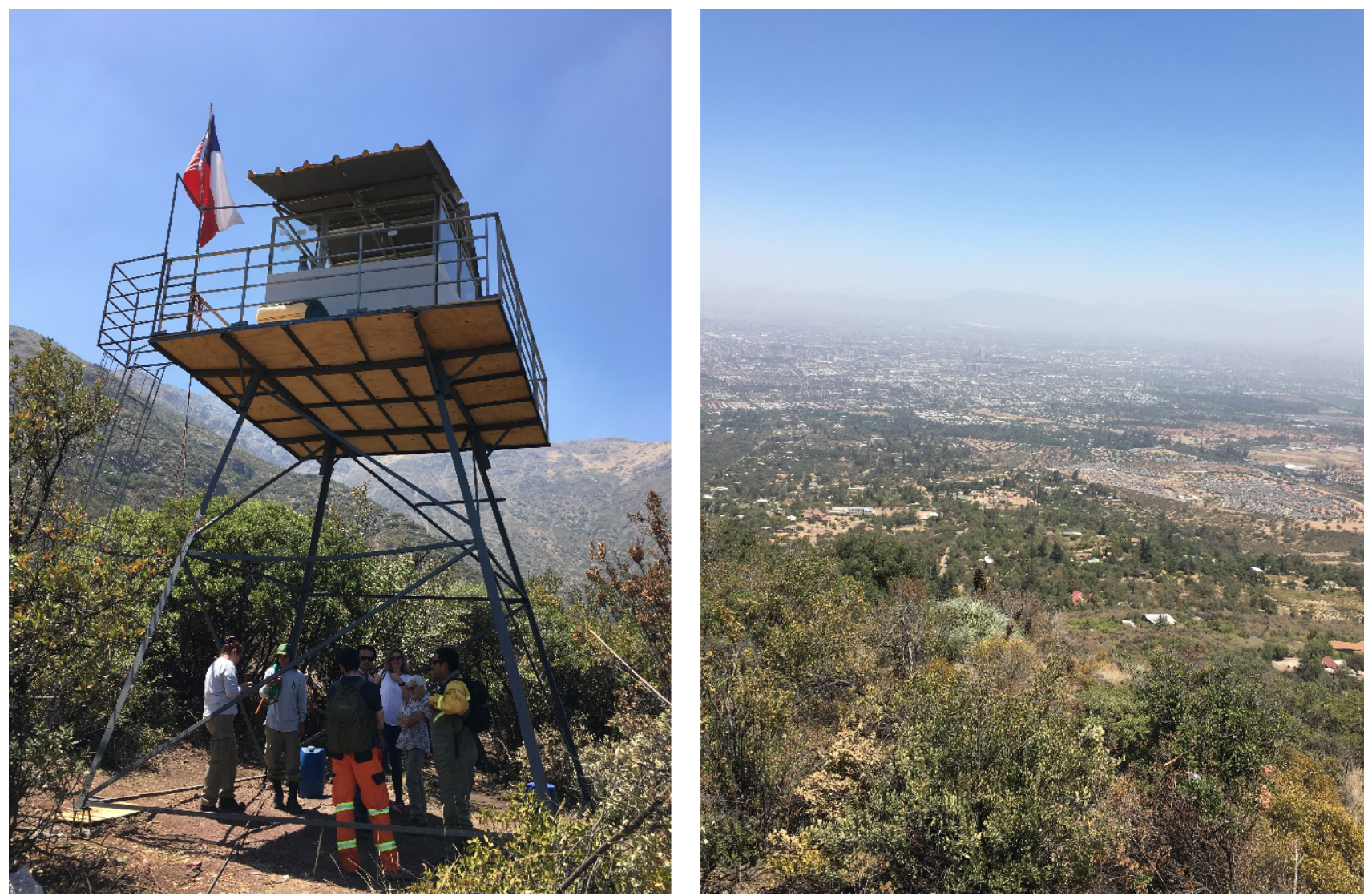

Figure 5. From left to right: The BEAF watchtower and its view of Santiago. Source: Authors in January 2018.

which are closely connected to our Rancièrean frame, can potentially recover the political through a long-term work of risk management in the urban margins. We discuss this in the next section, as central characters of the interaction of both risk management modes.

\section{Discussion}

The results presented depict a process of exclusionary urban development, in line with a techno-managerial mode of governing disaster risks. On top of the known exposure to floods and landslides, a significant proportion of the local residents are vulnerable. This is critical in a setting that for decades lacked preparedness and emergency awareness initiatives. In this sense, the technologies implemented for governing risks are different to those described by Zeiderman (2012): While he expands on the emergence of planning practices and techniques that construct an active relation between the State and citizens, in our case this is reduced to advance physicalist interventions and regulation of development. Here, risk management is carried out solely by the implementation of land use and the construction of mitigation infrastructure-while providing a laissez-faire developmental logic for real estate companies.

Transforming such mode of policing risks, as any regime (re)producing injustices, is at the core of a critical urban lens. In our view, this required to identify ways to politicise governance and thus recover the politics in the city (Davidson \& Iveson, 2015). To contest it, a disruptive moment must be found, which echoing Dikeç (2017), exist within the same logics of the police. Along with this, we expanded on the emergence of the BEAF as a marked step forward in terms of risk prevention and education. Their practices and discourse are enhancing an alternative way of risk management. A crucial question is how the presence of the BEAF, the increased community participation, and discussion of risk, might disrupt the dominant mode of risk management. In this sense, if we follow the notion that genuine political moments are rare and infrequent, and aimed at perturbing the order of things, it is unlikely to address the foundation of the BEAF as a political moment. The foothills are still ruled by processes which cause environmental degradation, leave neighbourhoods at risk, and which do not emancipate communities from long-standing exclusionary processes. Despite this, through the interaction of the police and the BEAF, an experiment towards more sustainable and resilient living in the foothills might be emerging. This interplay is embedded in the BEAF's features mentioned earlier: its egalitarian logic, its emergence 'at the margins,' and its formation of subjectivities.

First, the BEAF emerged with an egalitarian logic: being equal with the community of the foothills is a given throughout its work. The BEAF learnt from past experiences such as the 1993 disaster, the 90s envi- 
ronmental mobilisation, and the recent floods. Unlike the dominant mode, it works in an inclusive and integrative manner by principle, educating people and enhancing their knowledge of local risks. In that sense, it brings forth and enacts a common understanding of hazard vulnerability through an inclusive and egalitarian discourse. Second, emerging at the margins is important in a double meaning: located at the geographical margins of Santiago, and in an institutional margin given the absence of State-sanctioned organisations in the area. This makes the foothills a breeding ground for organising urban risk initiatives that contest the dominant paradigm. Local risk management efforts such as the BEAF extend beyond formal and informal distinctions, emerging at the crossroads of institutional recognition. The foothills are thus an example of Rancière's 'in-between spaces' where politics can be staged (see also Biskupovic, 2015). Finally, the engagement of such initiatives brings new subjectivities. Through the BEAF's work, unmanaged risks are no longer invisible. On the contrary, more people realise the fragility of the environment in which they live and the role of the current trend of rampant urbanisation in that. From this, the inhabitants of the foothills enhance a more autonomous way of managing risk, against the hierarchical and technocratic form of risk governance. By recognising their vulnerabilities and discussing their risks, the BEAF is contributing to dissent regarding State institutions and private developers.

Ultimately, the present conditions of risks show the co-existence of different modes of governing risk, as described in other urban domains by Choplin (2016). The interplay between these modes is still evolving and it is difficult to predict their course. The BEAF and the ongoing contestation of the Network could be demobilised as occurred to the 1990s movement, or furthermore, it could be co-opted by wider forms of governance (Uitermark \& Nicholls, 2014). Equally, the extent to which these developments are framed as resistance and resilience (Boano, 2017), or expanded as a further feature of neoliberal governance as self-responsabilisation (Nygren, 2018), is yet to be seen. We argue that through the interaction of these modes, there is potential to transform the dominant mode. An alternative, egalitarian mode that is explicitly intervening on the 'distribution of the sensible' is emerging, but it is not there yet. We will see how this marginal community, demanding for decades to live in a sustainable environment, can imagine and unlock a more just and inclusive urbanisation.

\section{Conclusion}

Current urban challenges highlight the need for new policies and governing arrangements. As profoundly political entities, cities are tensioned by power relations and these new policies are no exception. Beyond the truism that everything is political, critical urban studies are increasingly showing the dynamics of de- and repoliticization for such urban arrangements. Our purpose in this article has been to understand such dynamics for different modes of risk management, reflecting on their results regarding justice and inclusion. To do so, we followed the work of Rancière and showed how the State's role in managing risk can render disaster risk as something technical and invisible. In the interstices of this policing order, local communities organise emergent initiatives that are disrupting the visible and sayable. These modes are still evolving and coexisting on the ground, but we have shown initial efforts which potentially disrupt the trend of risk creation, and which hence advance more inclusive cities.

This article aimed to know under what conditions the interplay of these modes can move towards this more inclusive trend and what the role of politics is in that process. Our analysis shows that in order to advance in a more inclusive direction, bottom-up modes of risk governance must follow egalitarian principles, emerging through in-between spaces, and enact initiatives of subject formation. These features, which we described for the BEAF, are central in Jacques Rancière's view of politics. Nonetheless, we also described that the BEAF is not a counter-hegemonic initiative in the sense of being explicitly a disruptive endeavour aiming to transform society. The BEAF's foundation is, in Rancière's logic, not a 'properly political' moment, as it does not aim for a radical disruption of the police.

While it is not an exceptional politics, the emergence of the BEAF and associated risk management have the potential to shift the dominant mode, although in a different way. We see it less as a disruptive moment and more as an incremental one. The BEAF occupies a position balancing the police order and the more bottom-up potential for interrupting that governance. In this sense, the inhabitants of the foothills are experiencing an ongoing recovery of the political, but their context is still widely governed by the police. This view of politics contrasts to the position of Jacques Rancière and it is closer to Davidson and Iveson (2015), and potentially to Boano's (2017). We thus argue that incremental transformations in the domain of risk management can still contribute to enhance a renewed view of politics.

Finally, our analysis shows the theoretical contributions that Jacques Rancière can bring to address ongoing urban challenges, particularly to governing risks and inclusive cities. Although many planning initiatives have good intentions, they can produce exclusionary results that should be better understood and further resisted. We recognise that an inclusive governance process of disaster risk is complex and needs technical advances through infrastructure and land-uses. However, the tensions of these with inclusion and sustainability need socially-embedded and egalitarian forms of risk management, such as the one we described. Based on Rancière, we offered a way to understand the interplay of divergent sets of urban risk initiatives, while expanding a more radical politics therein. This requires urban planning and risk management to move beyond consensus-based gov- 
ernance and focus instead on the role of dissent and disruptive politics.

\section{Acknowledgments}

We thank Eva Costa de Barros, Malin Olofsson, and two anonymous reviewers for their comments on an early draft of the article. This work has been financially supported by the Becas Chile Doctoral Program Scholarship \#72170272 from the Government of Chile and the Governance and Inclusive Development Group of the Amsterdam Institute for Social Science Research of the University of Amsterdam.

\section{Conflict of Interests}

The authors declare no conflict of interests.

\section{References}

Alvarez, M. K., \& Cardenas, K. (2019). Evicting slums, 'building back better': Resiliency Revanchism and disaster risk management in Manila. International Journal of Urban and Regional Research, 43(2), 227-249. http://doi.org/10.1111/1468-2427.12757

Biskupovic, C. (2015). From rural haven to civil political project: Utopian ideals and environmental protection in the precordillera, Santiago, Chile. Journal of Political Ecology, 22, 183-198.

Biskupovic, C., \& Stamm, C. (2016). When citizen mobilisations transform the Andean Foothills: The case of the group for the defence of the Precordillera. Journal of Alpine Research/Revue de Géographie Alpine, 104(1). http://doi.org/10.4000/rga.3253

Boano, C. (2017). Pathways towards the resilient city: Presupposition of equality and active justice in Bangkok, Thailand. In A. Allen, L. Griffin, \& C. Johnson (Eds.), Environmental justice and urban resilience in the Global South (pp. 137-152). New York, NY: Palgrave Macmillan.

Camus, P., Arenas, F., \& Lagos, M. (2016). Visión histórica de la respuesta a las amenazas naturales en Chile y oportunidades de gestión del riesgo de desastre [Historical overview of natural hazards response in Chile and opportunities for disaster risk management]. Revista de Geografia Norte Grande, 46, 9-20.

Choplin, A. (2016). Post-politics and subaltern (de)mobilization in an African city Nouakchott (Mauritania). Journal of Asian and African Studies, 51(4), 398-415. http://doi.org/10.1177/00219096 14548238

Chu, E., Anguelovski, I., \& Carmin, J. (2016). Inclusive approaches to urban climate adaptation planning and implementation in the Global South. Climate Policy, 16(3), 372-392. http://doi.org/10.1080/ 14693062.2015.1019822

Cutter, S. L., Osman-Elasha, B., Campbel, J., Cheong, S.M., McCormick, S., Pulwarty, R., . . . Ziervogel, G.
(2012). Managing the risks from climate extremes at the local level. In C. B. Field, V. Barros, T. F. Stocker, D. Qin, D. J. Dokken, K. L. Ebi, . . . P. M. Midgley (Eds.), Managing the risks of extreme events and disasters to advance climate change adaptation (pp. 291-338). Cambridge and New York, NY: Intergovernmental Panel on Climate Change (IPCC) Working Groups I and II and Cambridge University Press.

Davidson, M. (2016). Planning for planet or city? Urban Planning, 1(1), 20-23. http://doi.org/10.17645/ up.v1i1.604

Davidson, M. (2017). Governance. In M. Jayne \& K. Ward (Eds.), Urban theory: New critical perspectives (pp. 146-157). London: Routledge.

Davidson, M., \& Iveson, K. (2015). Recovering the politics of the city. Progress in Human Geography, 39(5), 543-559. http://doi.org/10.1177/ 0309132514535284

Delamaza, G. (2015). Enhancing democracy: Public policies and citizen participation in Chile. Oxford and New York, NY: Berghahn Books.

Dikeç, M. (2005). Space, politics, and the political. Environment and Planning D: Society and Space, 23, 171-188. http://doi.org/10.1068/d364t

Dikeç, M. (2017). Disruptive politics. Urban Studies, 54(1), 49-54. http://doi.org/10.1177/00420980166 71476

Dikeç, M., \& Swyngedouw, E. (2017). Theorizing the politicizing city. International Journal of Urban and Regional Research, 41(1), 1-18. http://doi.org/ 10.1111/1468-2427.12388

Fainstein, S. (2015). Resilience and justice. International Journal of Urban and Regional Research, 39(1), 157-167. http://doi.org/10.1111/1468-2427.12186

Ferguson, J. (1994). The anti-politics machine. "Development," depoliticization, and bureaucratic power in Lesotho. Minneapolis, MN: University of Minnesota Press.

Ferrando, F., Sarricolea, P., \& Pliscoff, P. (2014). Determinación de amenazas y análisis de riesgo del sector precordillerano de la Comuna de La Florida [Determination of hazards and risk analysis of the foothills area of La Florida comuna]. Santiago: Municipality of La Florida.

Fraser, A. (2016). The politics of knowledge and production of vulnerability in urban informal settlements. Learning from Bogota, Colombia. In M. Roy, S. Cawood, M. Hordijk, \& D. Hulme (Eds.), Urban poverty and climate change. Life in the slums of Asia, Africa and Latin America (pp. 221-237). London and New York, NY: Routledge.

Fraser, A. (2017). The missing politics of urban vulnerability: The state and the co-production of climate risk. Environment and Planning A, 49(12), 2835-2852. http://doi.org/10.1177/0308518X17732341

Fuentealba, R., Verrest, H., \& Gupta, J. (in press). Planning for exclusion: The politics of urban disaster governance. Politics and Governance, 8(4). http://doi. 
org/10.17645/pag.v8i4.3085

Garrido, N., \& Sepúlveda, S. (2012). Peligro de flujos de detritos en Quebrada de Macul, Región Metropolitana y propuestas de medidas de mitigación [Debris flow hazard in the Macul Ravine, Metropolitan Region, and proposal of mitigation measures]. In Actas XIII Congreso Geológico Chileno 13o (pp. 1015-1017). Antofagasta: Sociedad Geológica de Chile.

Gotham, K. F. (2016). Antinomies of risk reduction: Climate change and the contradictions of coastal restoration. Environmental Sociology, 2(2). http:// doi.org/10.1080/23251042.2016.1177363

Gotham, K. F., \& Greenberg, M. (2014). Crisis cities: Disaster and redevelopment in New York and New Orleans. London and New York, NY: Oxford University Press. http://doi.org/10.1093/acprof

Gupta, J., Pfeffer, K., Ros-Tonen, M., \& Verrest, H. (2015). An inclusive development perspective on the geographies of urban governance. In J. Gupta, K. Pfeffer, H. Verrest, \& M. Ros-Tonen (Eds.), Geographies of urban governance: Advanced theories, methods and practices (pp. 217-228). New York, NY: Springer. http:// doi.org/10.1007/978-3-319-21272-2

Gutiérrez, C. (1997, December 2). Piden congelar edificación en precordillera [A claim to freeze edification in the foothills]. La Tercera.

Gutiérrez, P. (1997, November 26). Vecinos protestaron con taco en rotonda [Neighbours protested with jam in roundabout]. La Tercera.

Harvey, D. (1989). From managerialism to entrepreneurialism: The transformation in urban governance in late capitalism. Geografiska Annaler. Series B, Human Geography, 71(1), 3-17.

Hewitt, K. (1983). The idea of calamity in a technocratic age. In K. Hewitt (Ed.), Interpretations of calamity: From the viewpoint of human ecology (pp. 3-32). Winchester: Allen \& Unwin.

Huang, S. (2018). Understanding disaster (in)justice: Spatializing the production of vulnerabilities of indigenous people in Taiwan. Environment and Planning E: Nature and Space, 1(3), 382-403. http://doi.org/ $10.1177 / 2514848618773748$

INE. (2017). Censo nacional de población y vivienda [National census of population and housing]. Santiago: Instituto Nacional de Estadísticas. Retrieved from https://www.censo2017.cl

Ingenieros. (1994). Proyecto para control de aluviones en Quebrada de Macul [Project to contro alluviums in the Macul Ravine]. Revista Ingenieros, 1994(October), 52-55.

Ingram, J. C., Franco, G., del Rio, C. R., \& Khazai, B. (2006). Post-disaster recovery dilemmas: challenges in balancing short-term and long-term needs for vulnerability reduction. Environmental Science and Policy, 9(7/8), 607-613. http://doi.org/10.1016/j.envsci. 2006.07.006

Kaika, M. (2017). 'Don't call me resilient again!': The new urban agenda as immunology...or... what hap- pens when communities refuse to be vaccinated with 'smart cities' and indicators. Environment and Urbanization, 29(1), 89-102. http://doi.org/10.1177/ 0956247816684763

Keucheyan, R. (2013). The left hemisphere. Mapping critical theory today. London and New York, NY: Verso.

Koster, M., \& Nuijten, M. (2016). Coproducing urban space: Rethinking the formal/informal dichotomy. Singapore Journal of Tropical Geography, 37(3), 282-294. http://doi.org/10.1111/sjtg.12160

$\mathrm{Li}, \mathrm{T}$. M. (2007). The will to improve. Governmentality, development, and the practice of politics. London and Durham, NC: Duke University Press.

May, T. (2008). The political thought of Jacques Rancière. Creating equality. Edinburgh: Edinburgh University Press.

Meerow, S., \& Newell, J. P. (2016). Urban resilience for whom, what, when, where, and why? Urban Geography, 40(3), 1-21. http://doi.org/10.1080/02723638. 2016.1206395

Mitlin, D., \& Satterthwaite, D. (2016). On the engagement of excluded groups in inclusive cities: Highlighting good practices and key challenges in the Global South. Urban Development Series Knowledge Papers, 2016(21). Retrieved from https://openknowledge. worldbank.org/handle/10986/18027

MOP. (2006). Catastro de Obras en Cauces Naturales y Areas de Restricción. Vol II, Tomo 2. Etapa II: Catastros de Obras Menores en Cauces Naturales del Gran Santiago [Registry of works in natural water courses and restriction areas. Vol II-2. Stage II: Registry of minor works in natural water courses of the greater santiago]. Santiago: Ministerio de Obras Públicas, Dirección General de Aguas, Unidad de Fiscalización.

Mouffe, C. (2005). On the political. London and New York, NY: Routledge. http://doi.org/10.2307/2057923

Muñoz, O. (1990). Quebrada de Maul: Un factor de desequilibrio físico en la Comuna de La Florida [Macul Ravine: A factor of physical imbalance in the La Florida comuna]. Revista Geográfica de Chile: Terra Australis, 32, 103-134.

Nygren, A. (2016). Socially differentiated urban flood governance in Mexico: Ambiguous negotiations and fragmented contestations. Journal of Latin American Studies, 48(2), 335-365. http://doi.org/10.1017/ S0022216X15001170

Nygren, A. (2018). Inequality and interconnectivity: Urban spaces of justice in Mexico. Geoforum, 89, 145-154. http://doi.org/10.1016/j.geoforum.2017. 06.015

Oliver-Smith, A., Alcántara-Ayala, I., Burton, I., \& Lavell, A. (2017). The social construction of disaster risk: Seeking root causes. International Journal of Disaster Risk Reduction, 22(November), 469-474. http://doi.org/ 10.1016/j.ijdrr.2016.10.006

ONEMI. (1995). Serie Estudio de Caso: Aluvión de la Florida ocurrido el 3 de mayo de 1993 [Case study series: La Florida Alluvium of 3 of May 1993]. Santiago: 
Oficina Nacional de Emergencia.

P.C. (1996, December 9). Megaproyecto inmobiliario en Macul Alto será desarrollado en 20 años [Real estate megaproject in Macul Alto will be developed in 20 years]. La Época.

Pelling, M. (2003). The vulnerability of cities: Natural disasters and social resilience. London: Earthscan.

Pelling, M. (2011). Urban governance and disaster risk reduction in the Caribbean: The experiences of Oxfam GB. Environment and Urbanization, 23(2), 383-400. http://doi.org/10.1177/0956247811410012

Rancière, J. (1991). The ignorant schoolmaster. Five lessons in intellectual emancipation. Palo Alto, CA: Stanford University Press.

Rancière, J. (1999). Disagreement: Politics and philosophy. Minneapolis, MN: University of Minnesota Press.

Rancière, J. (2006). Hatred of Democracy. London and New York, NY: Verso.

Rancière, J. (2010). Dissensus. On politics and aesthetics. London and New York, NY: Continuum.

Rebotier, J. (2012). Vulnerability conditions and risk representations in Latin-America: Framing the territorializing urban risk. Global Environmental Change, 22(2), 391-398. http://doi.org/10.1016/j.gloenvcha. 2011.12.002

Rojas, R. (1996, December 5). Corte respaldó construcción en Lo Cañas [Court backed the construction in Lo Cañas]. La Tercera.

Sandoval, V., \& Voss, M. (2016). Disaster governance and vulnerability: The case of Chile. Politics and Governance, 4(4), 107-116. http://doi.org/10.4324/ 9781315463896

Sepúlveda, S. A., Rebolledo, S., \& Vargas, G. (2006). Recent catastrophic debris flows in Chile: Geological hazard, climatic relationships and human response. Quaternary International, 158(1), 83-95. http://doi. org/10.1016/j.quaint.2006.05.031

SEREMI-MINVU, \& INDUAMERICANA. (2014). Análisis Áreas Riesgo Precordillera Vitacura y La Florida [Analysis of risk areas in the foothills of Vitacura and La Florida]. Santiago: Secretaría Regional de Vivienda y Urbanismo, Región Metropolitana.

Soja, E. W. (2010). Seeking spatial justice. London and Minneapolis, MN: University of Minnesota Press.

Swyngedouw, E. (2007). The post-political city. In BAVO (Ed.), Urban politics now. Re-imagining democracy in the neoliberal City (pp. 58-76). Rotterdam: NAI Publishers.

Swyngedouw, E. (2009). The antinomies of the postpolitical city: In search of a democratic politics of environmental production. International Journal of Urban and Regional Research, 33(3), 601-620. http:// doi.org/10.1111/j.1468-2427.2009.00859.x

Swyngedouw, E. (2010). Post-democratic cities. For whom and for what. Paper presented at the Regional Studies Association Annual Conference, Budapest, Hungary.

Swyngedouw, E. (2011). Interrogating post-democratization: Reclaiming egalitarian political spaces. Political Geography, 30, 370-380. http://doi.org/ 10.1016/j.polgeo.2011.08.001

Uitermark, J., \& Nicholls, W. (2014). From politicization to policing: The rise and decline of new social movements in Amsterdam and Paris. Antipode, 46(4), 970-991. http://doi.org/10.1111/anti.12025

UNDRR. (2017). Terminology on disaster risk reduction. UNDRR. Retrieved from https://www.unisdr.org/we/ inform/terminology

UNISDR. (2015). Sendai framework for disaster risk reduction 2015-2030. Geneva: UNISDR, The United Nations Office for Disaster Risk Reduction. Retrieved from https://www.preventionweb.net/files/43291_ sendaiframeworkfordrren.pdf

Vale, L. J. (2014). The politics of resilient cities: Whose resilience and whose city? Building Research \& Information, 42(2), 191-201. http://doi.org/10.1080/ 09613218.2014 .850602

Velicu, I., \& Kaika, M. (2017). Undoing environmental justice: Re-imagining equality in the Rosia Montana antimining movement. Geoforum, 84, 305-315. http:// doi.org/10.1016/j.geoforum.2015.10.012

Weinstein, L., Rumbach, A., \& Sinha, S. (2019). Resilient growth: Fantasy plans and unplanned developments in India's flood-prone coastal cities. International Journal of Urban and Regional Research, 43(2), 273291. http://doi.org/10.1111/1468-2427.12743

Zeiderman, A. (2012). On shaky ground: The making of risk in Bogotá. Environment and Planning A, 44(7), 1570-1588. http://doi.org/10.1068/a44283

Zeiderman, A. (2013). Living dangerously: Biopolitics and urban citizenship in Bogotá, Colombia. American Ethnologist, 40(1), 71-87. http://doi.org/10.1111/amet. 12006

\section{About the Authors}

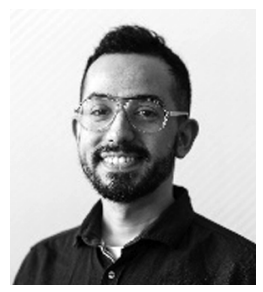

Ricardo Fuentealba is a PhD Candidate at the Governance and Inclusive Development programme group of the AISSR of the University of Amsterdam. His doctoral research centres on understanding how post-disaster recovery and reconstruction processes are transforming urban contexts in relation to future risks. He holds an MSc in Human Geography from the University of Bristol. Having experience in the Chilean Public Sector and Latin American NGOs, he has published on environmental politics, regional and local development, urban culture, and indigenous development policy. 
Hebe Verrest is Associate Professor in International Development Studies at the University of Amsterdam. Having a background in Human Geography, she has a strong interest in the spatial dimensions of development issues, particularly those related to urbanization and cities. Leading in her work is a focus on exclusion and inequality. These themes come back in more specific topics that she works on such as climate adaptation, urban governance, urban flooding, smart city, and entrepreneurship. Geographically, her expertise is in small and medium cities in The Caribbean, and increasingly on coastal cities in South Asia. 